Ippei Shimamura*

\title{
Magicalized Socialism: An Anthropological Study on the Magical Practices of a Secularized Reincarnated Lama in Socialist Mongolia
}

\author{
https://doi.org/10.1515/asia-2019-0038
}

\begin{abstract}
Socialist regimes lead by the Soviet Union were one of the great experiments for human life "without religions". In Mongolia, as in other socialist countries, modernity was constructed by expelling religious practices from the sphere of everyday life in the name of atheism. However, modernity has never completely succeeded in fully establishing secularization anywhere in the world, and the phenomena of magico-religious practices continue and even are rampant, not least behind the facades in post-socialist countries. In other words, it can be said that the affiliation between secularization, de-sacralization, and modernity, which many scholars imagined, was just fantasy. Following the way in which Talal Asad examines the "novel" form of secularism present in Euro-American societies, it becomes quite easy to understand that socialist modernity was formulated as the "novel secular" by the Soviet Union. While examining Soviet-style atheism or Soviet-formed secularization, we need to rethink the practices that are "in between" the religious and the secular. Mongols have been practicing religion secularly. We see this in how selecting reincarnated lamas has been a political act, and in the way they have been practicing secular politics so religiously - for example, the importance of fortune telling and shamanism in political decision-making. Further, we need to note that the socialist expulsion of institutional aspects of religions such as churches, clergies, and religious scriptures resulted in the spread of magical/occult practices. In this paper we explore Mongol practices that are in between the religious and the secular by examining Buddhist practices in Zavkhan Province, where people maintained strong worship for reincarnated lamas secretly and in disguise during the socialist era.
\end{abstract}

*Corresponding author: Ippei Shimamura, National Museum of Ethnology, 10-1 Senri Expo Park, Suita, Osaka 565-8511, Japan. E-mail: ippei@idc.minpaku.ac.jp; ippeishimamura@hotmail.co.jp 
Keywords: Buddhism, magicalized socialism, Mongolia, reincarnated lama, secularization, post-socialism, religion, Buddhified socialism, socialized Buddhism, simultaneous causality circle model

\section{Introduction}

The socialist regimes lead by the Soviet Union between 1917 and the early 1990s have been said to have been one of the great experiments for human life without religions. In Mongolia, as in other socialist countries, modernity was constructed by expelling religious practices from the sphere of everyday life under the socialist principle of atheism. In fact, secularization was never totally accepted in these socialist societies, and even more, the phenomena of magico-religious practices, including the occult, grew and continue to be rampant behind the scenes in post-Socialist countries. In other words, it can be said that the affiliation between secularization, de-sacralization, and modernity, which many scholars described ${ }^{1}$ was just, in Casanova's word, "myth", even in the case of the former Socialist countries. It is quite easy to understand that socialist modernity was formulated as the "novel secular" by the Soviet Union, following the way in which Talal Asad examines the "novel" form of secularism present in Euro-American societies, where he demonstrates that the United States tends to use the Manichaean religious tones of "good" and "evil" in their diplomatic comments despite their denomination of themselves as a "secular" state. ${ }^{3}$ Asad's theory was a kind of Copernican Revolution in "secularity" because he revealed that western modernity has never produced an authentic secular state and/or society but has delivered something like a religious society which calls itself "secular".

So, what about modernization and secularization brought by socialism? It is well-known that previous socialist countries like the Soviet Union and Mongolia officially espoused atheism. If so, did socialist modernity really produce thoroughly secular societies? Curiously enough, most studies on religious phenomena in the post-socialist regimes regard the phenomenon as the "revival of religions". 4 Similarly, religious "conversion" after socialism has been pointed out by some studies, ${ }^{5}$ but focusing on conversion shares a common weakness

1 Durkheim 2001 [1912]; Weber 1993 [1920]; etc.

2 Casanova 1994: 11-19.

3 Asad 2003: 7.

4 e.g. Lewis 2000; Kollmar-Paulenz 2003; Yamada 2004; Menzel 2007; Hann 2010; Buyandelger 2013.

5 e.g. Pelkmans 2009. 
with the concept of "revival", in that they both rule out the religious continuity between socialism and post-socialism, an aspect which I criticize later on. Morten Pederson also has asserted "shamanism without shamans" in postsocialist Mongolia; his argument is based on the unsupported assertion that "genuine" shamans have all gone because of socialist repression. ${ }^{6}$

However, using the term "revival" implies that every religious practice was suppressed in socialist times, whatever the religion was. That's why religion "revived" after the collapse of the socialist regimes. In other words, these revivalist approaches are unable to account for the continuity that can be found through socialist time and into post-socialist time, in terms of religious practices, even though there were still active religious practices even under the soviet socialist regimes. The prefix "post", however, does not necessarily mean discontinuity with the past. For instance, we see a clear continuity between "colonial" and "post-colonial"; after the end of political colonialism, no one would ever conceive of post-colonial countries as totally liberated from colonial rule, because many post-colonial countries are still economically dominated by western and/or global economies. What is the continuity of religious practices between socialist time and post-socialist time, then? There are few studies that have examined the continuity of religious practices and way of thinking between socialist era and post-socialist era.

Thomas Luckmann was right when he found religious practices in people's everyday life under the socialist regimes, ${ }^{7}$ but it is doubtful whether religions were actually "secluded to private spheres" in socialist time, as he concluded. Benningsen proclaimed that the more Soviet authority oppressed religions, the higher the ratio of religious practices became in Central Asia. ${ }^{8}$ Mark Juergensmyer discussed the "love-hate relationship" between religion and socialism ${ }^{9}$ because he sees that socialism might be compatible with religions to some extent. Caroline Humphrey pointed out the complementary relationship between shamanism and the Communist Party in Siberia: Shamanism is undogmatic, fluid, transient, has no commandments, no hierarchical structure, and only provides "explanation of suffering." ${ }^{10}$ Her account can explain the continuity, or survival and revival of shamanism during and after socialist times. By

6 Pedersen 2011: 5; 224. Pedersen's claim that there were no shamans is unreliable because I observed several active shamans in his field, or the Lake Khövsgöl area in 1996-1997 before he started fieldwork there. Moreover, Judith Hangartner collected in-depth data in her fieldwork, and she counted 60 shamanizing persons in late 90's in the area as well (Hangartner 2011: 5).

7 Luckmann 1967.

8 Benningsen 1989.

9 Juergensmyer 1993.

10 Humphrey 1998. 
contrast Buddhism, the major religion for Mongol Buryats, was still thought to be a rival or opponent to the Communist Party. As an anthropologist of shamanism, what I have clarified is that shamanism among Buryats in Mongolia was practiced throughout the socialist era, and "re-vitalized"11 after the collapse of socialism. I have explained that becoming a shaman is an act of searching for his/her lost roots: a large number of Mongol Buryats lost their genealogical continuity because of the 1930's great purge against Buryats. ${ }^{12}$ Takizawa asserted that Buddhism in Mongolia has intentionally "privatized," and could survive as "house-hold rituals" in socialist Mongolia. ${ }^{13}$

The above studies on religions during the socialist era have strong affinity with the "religious revivalism" theory. If so, a question rises up immediately: should the religious revival be considered merely as the de-privatization of religions; ${ }^{14}$ that is, did religions become apparent just by moving from the private sphere to the public sphere ${ }^{15}$

It can be said, at least, that these accounts have ignored the continuity of religious practices between socialist time and post-socialist time. Empirically, I know local scholars in Mongolia consistently complain that Western scholars use the terms "religious oppression" and "revival" when they discuss the religions of the socialist and post-socialist eras. The term "revival", for local scholars, connotes the discontinuation of "traditionality" of religions: the implication is that traditions weren't inherited from socialist to post-socialist era because they were cut off. The revivalists' discourse, in this perspective, is considered not only as false analysis but also offensive. In other words, local people including local scholars don't think their religion and /traditions were cut off but rather that they continued even in the socialist era.

Moreover, the revivalists have paid little attention to local people's "subjectivity" of the religious practices during the socialist time, emphasizing religious oppression by Communist Party.

However, there are some Western scholars, in fact, who support the continuity of religious practices between socialist time and post-socialist time. Judith Hangartner rightfully indicated that socialism was not a homogeneous period and post-socialism is not entirely distinct from the preceding socialist past. Rather,

11 Known as a well-versed anthropologist on Siberian Shamanism, Majorie Mandelstam Balzer, who has conducted fieldworks in Siberia since late 80's, also has used the term "revitalization" rather than "revival" but when it comes to post-socialist shamanism. See her work (Balzer 2011).

12 Shimamura 2002; 2004; 2011; 2014.

13 Takizawa 2016.

14 Casanova 1994.

15 Hann 2010. 
post-socialism may be approached as a heterogeneous amalgam of socialist legacies and maintenance of pre-socialist habits, blended with global neoliberal transformations and with the new esteem for traditional cults and values. ${ }^{16}$ Anya Bernstein admitted the religious continuity between socialism and post-socialism, and even with pre-socialism. Analyzing the religion and politics of the Buryat Buddhist population in Siberian Russia, she argued Buryats have adopted social changes such as the Russian Revolution, Soviet secularization, and the fall of socialism, using the concept of "body politics" in order to connect with the Russian State and/or World Buddhist community. ${ }^{17}$ Ngo and Quijada have also presciently pointed out that, despite the widespread perception that communism and atheism are inseparable, throughout the communist and post-communist world, religious and political imaginaries are intimately intertwined: Ho Chi Minh was made a god in the religion of Vietnamese Nationalism, and in China, Mao's mangos became political relics. ${ }^{18}$ I will discuss later on the point that religions did not virtually disappear from the public sphere in socialist time but survived even in the public sphere in tandem with everyday communist practice.

What is more, these revivalist approaches can't explain the strong emergence of non-institutionalized religions in post-socialist countries. We know that occultism and magical practices are rampant in post-socialist Russia. ${ }^{19}$ Grishaeva and Shumkova's statistical studies in Sverdlovsk Oblast show that even believers of Russian Orthodoxy have strong positive attitudes to magic irrespective of gender, age, and educational levels. ${ }^{20}$

The strong affinity to magic and occult things is not limited to Russia, but is common in post-socialist countries. According to Pollack, in Eastern Europe, traditional Christian churches are increasingly losing their social significance, and new forms of religion, which are not so highly institutionalized and more syncretistic, are emerging. ${ }^{21}$ Similarly, in Mongolia, shamans dramatically increased after the fall of socialism. Quite intriguingly, people became shamans regardless of their ethnicity, gender, or economic position. I have discussed how, in this "plague of shamans" phenomenon, individual shamans overturn existing social relationships, rend apart social bonds, and, further, shake apart and tear what is considered to be ethnic knowledge. ${ }^{22}$

16 Hangartner 2011: 5.

17 Bernstein 2013.

18 Ngo / Quijada 2015: 2.

19 cf. Lindquist 2006; Fujiwara 2010; Shnirelman 2017.

20 Grishaeva / Shumkova 2017.

21 Pollack 2003.

22 Shimamura 2017. 
Concurrent with the plague of shamans' phenomena, reincarnated lamas, most of whom were purged or even executed in the 1930's, have been springing up like mushrooms after a rain all over Mongolia since the collapse of socialism. Lamas are venerated by local people not because of their knowledge of religious philosophy and theory but because of their magical ability. They are believed to have some kind of supernatural and/or magical power; they are known as "chadaltai khün", literally a person with ability, or "nomtoi khün" literally a person with books, i. e. a knowledgeable person. ${ }^{23}$

What I would like to hypothesize here is that socialism, especially late socialism, didn't bring atheism; rather, it enhanced magical ideas in people's everyday life, both in public space and private space. That's why we can say that magical practices have been "continually" practiced throughout the time of socialism and into post-socialism. Socialism largely expelled the four major institutional constituents of religion from the social space: clergy, religious scriptures, church/ temples, and public rituals. Only magical constituents of religious practices could survive in people's everyday life throughout the socialist era. For example, it was common in Mongolia that newly-born children be given names in the Tibetan language by ex-monks in socialist time because giving the "right" name to infants was traditionally believed to be indispensable in order to repel death and sickness. That's why quite large numbers of Mongols have Tibetan names even now.

In this paper, I will explore the hypothesis of widespread observance by Mongols of practices in between the religious and the secular by examining Buddhist practices in Zavkhan Province, where people maintained strong worship for reincarnated lamas "secretly" during the socialist era. In terms of methodology, I conducted anthropological fieldworks in Zavkhan and the capital Ulaanbaatar for two and a half weeks in the summer of 2016. I collected relevant materials on the theme at some libraries in Ulaanbaatar, as well.

Regarding the term "magic", I do not invoke the Frazer's worn-out notion of the "pseudo-technical event" based on the "untrue", 24 but support Wittgenstein's highly suggestive idea: magic gives a wish a representation; it expresses a wish such as technics does. ${ }^{25}$ In other words, as the Japanese anthropologist Mitsuru Hamamoto asserts, magical practices can most helpfully be characterized by not as subscribing to the incorrect theory but as abandoning the search for the evidence/reason. ${ }^{26}$ So we need to admit the similarity between magical practices and using modern technology, and that's why magic cannot be said to be simply "superstition" either.

23 Shimamura 2018.

24 Frazer 1998 [1890].

25 Wittgenstein 1965.

26 Hamamoto 1997. 


\section{Socialized Buddhism and Buddhified socialism (1944-1992)}

Before examining magicalized practices of people's everyday life in socialist times which were related to ex-reincarnated lamas, let me briefly give an overview of the history of Mongolian Buddhism in the twentieth century. Generally, any kind of religion in socialist countries was thought to be severely suppressed by atheist policy. However, in fact, Buddhist monasteries and the Mongolian People's Revolutionary Party (hereafter MPRP) constructed a subtle mutual dependence relationship after 1944. This mutual dependence was restricted to the public sphere and inside Buddhist monasteries, and thereby the restriction led local Mongols to practice "magic." In other words, after World War II, the public sphere in Ulaanbaatar was "Buddhified," and on the other hand, Buddhist institutions were "socialized" as I explain below.

Soon after the fall of the Qing dynasty in 1911, northern Mongolia, i. e. today's State of Mongolia, declared independence by enthroning the top-ranked lama, the eighth Jebtsundamba Khutuktu, as the Bogd Khan (holy emperor). However, after the death of Jebtsundamba in 1924, the theocratic system was immediately abolished. The Soviet-backed communist government declared the establishment of the Mongolian People's Republic (hereafter MPR) in 1924, and banned recognition of any new incarnated lamas in 1928 by a resolution of the MPRP's 7th Congress. Furthermore, in the 1930's, amid the unceasing whirlwind of the Stalinists' religious oppression, almost all monasteries and temples were destroyed, and great numbers of reincarnated lamas and monks were executed because they were deemed as enemies to establishment of socialism.

However, the intensification of World War II made Stalin and his followers to decide to restore religion to a degree of prominence. This was not primarily as a means to stoke the fires of Russian nationalism but as a tool for restoring Soviet power to areas that the Red Army recovered from German occupation. ${ }^{27}$ In Mongolia, a very unique and subtle mutual dependence relationship between Buddhist monasteries and the Communist government started amid World War II .

According to Lkhagvademchig, who made detailed research on the diplomatic history of Mongolian Buddhism in the twentieth century, Mongolian Buddhists were promoted to carry out international activities, yet, domestically, they were restricted to conducting Buddhist affairs within the walls of Gandan monastery. ${ }^{28}$ First, Gandan Monastery, one of the biggest monasteries in

27 Miner 2003.

28 Lkhagvademchig 2018: 83. 
Ulaanbaatar, was re-opened in 1944 to time with the visit of U.S. Vice President Henry A. Wallace because the Mongolian government wanted to show him that the MPR respects freedom of religion. Then, in 1947, after the Central Religious Administration (CRA), the government agency or the authorities of religious activities, was established at Gandan Monastery, Gandan Monastery began to carry out international activities outside Mongolia under the direction of the government. For example, CRA invited Tsagaan Gegeen and Galsan Gegeen, topranked reincarnated lamas of Inner Mongolia, China, in 1950 and 1951. In 1956, Mongolia sent delegates to India in order to attend the celebrations for the 2500th anniversary of Buddha's birth. ${ }^{29}$

In following years, CRA accelerated the activity of sending delegates to foreign "Buddhist" countries such as China, India, Cambodia, and Thailand where the headquarters of the World Fellowship of Buddhist (WFB) was located. In 1970, when the Asian Buddhist Conference for Peace (ABCP), which was established by the initiative of the Soviet Union in opposition to the U.S.-led WFB, was organized at Ulaanbaatar, Ven. S. Gombojav, the abbot of the Gandan Monastery, was elected as the President of ABCP. ${ }^{30}$ Clearly enough, these surface freedom of religious activities were one component in the part of Soviet propaganda against the Western world.

Furthermore, the Buddhist Institute (Shashny Deed Surguul') was opened at Gandan Monastery under a resolution of the MPRP Politburo in the same year. In other words, the reproduction of Buddhist monks was restarted from that year, and the Institute accepted roughly 30 students in every year. ${ }^{31}$

Consequently, Buddhism was re-institutionalized in Mongolia by the MPRP and the Communist Party of the Soviet Union during and after World War II . What I would like to highlight here is that Mongolian Buddhism was socialized because their institutions were totally designed in the communist way. First, monasteries were controlled by the MPRP through the Advisor of Religious Affairs attached to the Cabinet (Said naryn derged Shashny khergiig erkhlekh zövlökh).

Secondly, Gandan Monastery itself was institutionalized in the communist way: Khambo lama, or the chief abbot, who was traditionally not a spiritual leader but merely the administrative leader who served only for several years, held office for an extremely long term in position, as if he was appointed the Secretary General of the Party. The Buddhist clergy was reorganized like the

29 Lkhagvademchig 2018: 75-92.

30 Lkhagvademchig 2018: 90.

31 Lkhagvademchig 2018: 75-92. 
socialistic bureaucracy: they got "zed (alms)" as a monthly salary, and worked like public servants. The fees for chanting sutras for protecting against misfortune by monks were formulated as flat-rate tariffs instead of voluntary donation [So, we can observe Chris Hann's notion of "religious market" 32 in that time, indeed]. Third, the traditional education system for monks was re-organized in a socialistic way: secular subjects such as Marxist philosophy, History of the MPRP, Modern Buddhism, Russian, and even English were taught at the Institute in addition to traditional Buddhist studies. ${ }^{33}$

As a matter of fact, this kind of change, or secularization, was quite common in other parts of the world, as well, because "Buddhist modernism" as influenced by Western modernity ${ }^{34}$ was a dynamic set of processes based on a plurality of local and global causes and emphasized that Buddhist revival processes in Asia were often combined with nationalist movements spurred by reactions to colonialism. ${ }^{35}$ What is distinctive in Mongolia's case, however, is that Buddhist modernity was constructed under the leadership of socialists, who originally held to atheist ideology. Moreover, the transformation process of religious institutions was not one-way, but interactive with the "secular" communist society.

Quite intriguingly, the secularized public sphere had been simultaneously "Buddhified" corresponding to Buddhist institutions being socialized. It was impossible to establish socialism without secularized Buddhist monks in Mongolia, because one-third of the male population were monks before the People's Revolution of 1921. Even though large numbers of monks were executed, secularized monks took major roles in many sectors in the new socialist regime: political leaders, scientific scholars, teachers, artists, and artisans. Political leaders like Kh. Choibalsan (in office as PM 1939-1952) and Yu. Tsedenbal (in office as PM 1952-1974), who were both supreme leaders of the MPRP, were monks when they were in childhood. The important point is that the ideas, values, and methodology of the Buddhist way had also permeated into the secular socialist society in Mongolia through ex-monks.

As another example, The Portrait of Lenin, which was painted by the outstanding Mongolian artist B. Sharav (1866-1939) in 1922, is famous for its Buddhist Thanka-painting style: there are bunches of lotus flowers drawn in front of Lenin (Figure 1). Sh. Luvsanvandan (1910-1983), a prominent Mongolian

32 Hann 2000.

33 Lkhagvademchig 2018: 92; Soninbayar 1995: 31.

34 McMahan 2008; 2012.

35 Havnevik 2017: 116. 


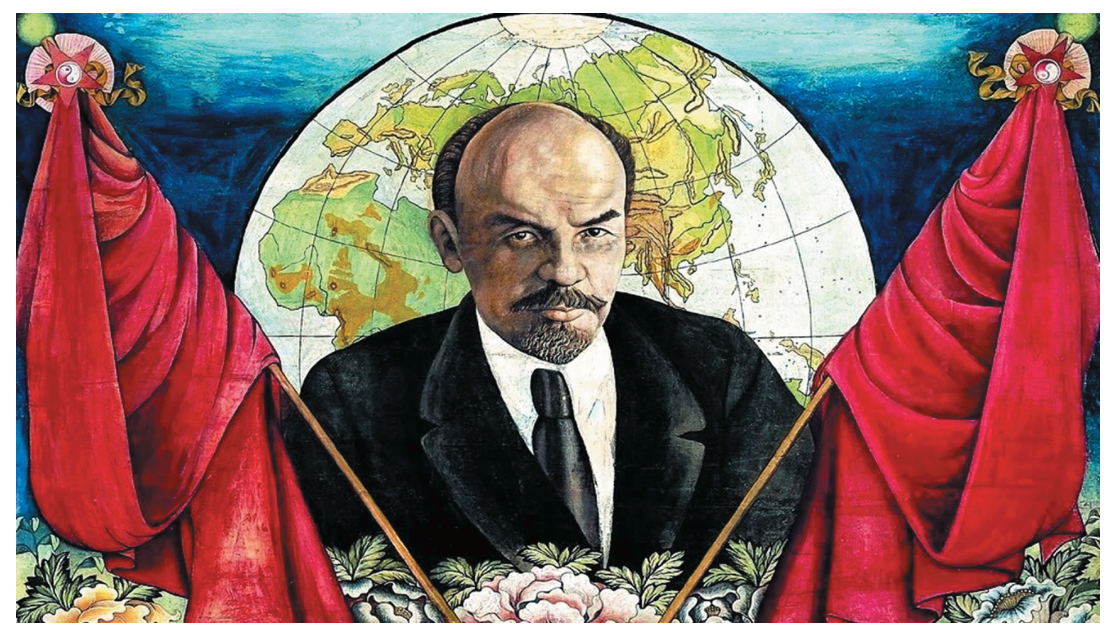

Figure 1: Lenin Bagsh (1922) by B. Sharav at the Mongolian modern art gallery.

linguist in the Socialist era, surprisingly tried to theorize Nagarjuna's Middle Way and Emptiness by connecting them to Lenin's philosophy. ${ }^{36}$ Socialist architecture was also Buddhified: a pair of guardian lions unfailingly stand at the entrance of public buildings such as government buildings, schools, hospitals, and museums, just as they guarded the entrance of Buddhist monasteries and temples before the revolution. School teachers were immoderately respected probably because the word bagsh, which corresponds to teacher, has another meaning: guru, or spiritual leader. Usually Mongols call the Dalai lama "Dalai bagsh", but they also called V.I. Lenin "Lenin bagsh" at the same time. Presumably, Lenin was respected by Mongols as if he were a guru in the socialist era. In short, establishing socialism must have owed much to "secularized" Buddhist monks in Mongolia.

What is perhaps even more significant is that some senior citizens told me that not only common people but also cadres of the MPRP used to ask monks in Gandan Monastery and ex-lamas for fortune-telling and chanting sutras against misfortune. They said there were even top executives of the party who asked monks to chant Buddhist sutras by sending their proxies to the monastery. One of the high-ranked lamas who worked at Gandan Monastery in the late socialist era gave evidence that the Advisor of Religious Affairs from the government

36 Luvsanvandan 1977. 
always consulted their convenience to increase the monastery's ration of foodstuffs and commodities because as the monk said, "Party cadres were actually Buddhists, as well".

Furthermore, it is quite natural that the MPRP adopted the lotus flower as their party emblem in the late 90's after the collapse of the socialist regime, saying in their party platform that their party's principle is based on Nagarjuna's philosophy. It is also understandable that Mt. Otgontenger was designated as National Holy Mountain (töriin takhilagat uul), and offered Buddhist rituals by the President of Mongolia in 2004. All of these were because the MPRP had already been Buddhified since socialist time.

In conclusion, throughout the socialist time, religion became neither extinct nor confined to private spheres. Rather, religion could survive both in private and public spheres; it is doubtful there were "private spheres" in the strict sense of the word in Socialist Mongolia. In other words, it is not appropriate to distinguish social space as a dichotomous category of public and private when it comes to the religious situation in the socialist era, because no matter whether private or public, people practiced something like religion despite it being restricted to some extent. Another significant point is that religious institutions had internalized and even incorporated socialism by accepting not only the party's control but also its ideology, and secular society also internalized and even incorporated Buddhism because ex-monks and their followers, who were still supportive of Buddhist faith, had major roles in socialist society in Mongolia.

As a result, unique and somehow contradictory socio-cultural sets were constructed in social space in the socialist era; that is, the cultural sets which were secular/atheistic but religious (buddhified), at the same time they were religious (Buddhism) but socialistic. Here I would like to call this contradictory socio-cultural construction the "Simultaneous Causality Circle Model," or Dependent-together-Origination Model (Chart 1). However, religious institutions could survive only in the capital, Ulaanbaatar, at Gandan Monastery, so basically it is true that socialism mainly expelled institutional constituents of religion - clergy, religious scriptures, church/temples, and public rituals from the social space. Hence, the Simultaneous Causality Circle Model might be limited within the confines of the capital Ulaanbaatar. So what happened in local society outside of the capital city? What I will demonstrate here is that this moment enhanced magicality in local society because local inhabitants lost the four institutional constituents of religion in their social space. These magical practices were closely related to secularized monks, and that's why I will examine Buddhist practices and an ex-reincarnated lama in Zavkhan province during the socialist era. 


\section{Simultaneous Causality Circle Model on Buddhism in Socialist Mongolia (1944-1990)}

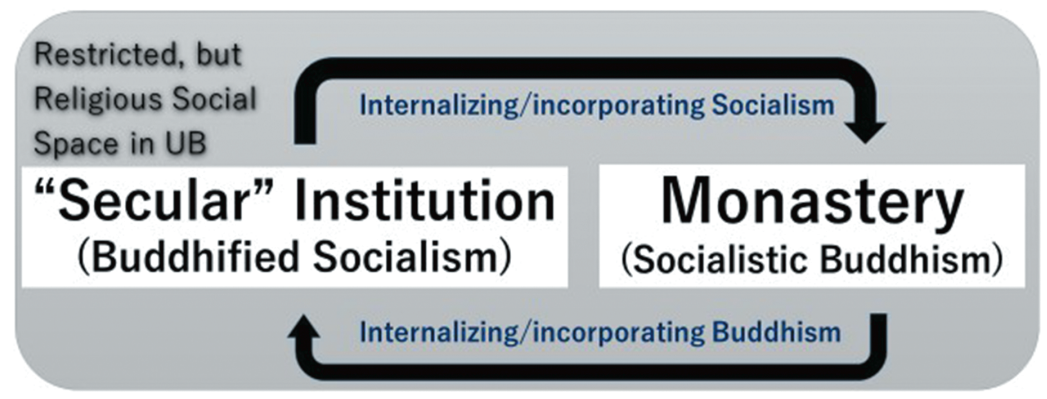

Chart 1: Simultaneous Causality Circle Model.

\section{Milarepa in Socialist Mongolia}

In order to understand people's everyday Buddhist practices in rural areas under socialism, I conducted fieldwork in Zavkhan Province, which is located in the middle west of Mongolia. The reason why I chose Zavkhan is, first, people in this province are well known to have strong faith in Buddhism, and the province is one of the biggest centers for Mongolian Buddhism despite it being a remote province whose provincial capital is $1100 \mathrm{~km}$ away from Ulaanbaatar. For example, in Zavkhan, there is a famous mountain named Otgontenger, whose peak is covered with a permanent glacier, and has been worshipped not only as the residence of wrathful protector Vajirapani (Mo. Ochirwan'), but also as a powerful emanation of the Buddha. ${ }^{37}$ Mongolia has been seen as the land of Vajirapani for a long time so that it can be said Zavkhan is the epitome of Buddhist Mongolia. Moreover, Chinggis Khan is retrospectively identified as an emanation of Vajirapani in the traditional Mongolian chronicles. ${ }^{38}$

On top of that, Zavkhan is famous for its large numbers of reincarnated lamas. According to Russian Orientalist Aleksei Pozdneyev, in the late nineteenth century there were 118 reincarnated lamas in Khalkha Mongolia, or today's State of Mongolia. ${ }^{39}$ In today's Zavkhan Province, there were 4 out of 13 lamas who were "officially recognized reincarnated lamas by the Qing dynasty” (Mo.Tamgatai khutagtu, or reincarnated lamas with official seals) in

37 Wallace 2015b: 183.

38 Wallace 2015a.

39 Pozdneyev 1993 [1887]: 238. 
Khalkh Mongolia: Jalkhanz Khutagtu, Yalguulsan Khutagtu, Narovanchen Khutagtu, Khamba Khutagtu Nomun Khan (Dashbadrakh 2004).

The 8th Jalkhanz Khutagtu Damdinbazar (1874-1923) was particularly wellknown because he worked as the 3rd Prime Minister of the Bogd Khanate Mongolia (1922.3-1923.6). The Diluv Khutagtu Jamsranjav (1883-1965), who fled from communist-ruled Mongolia to the United States and later worked for Mongolian independence, was also born in Today's Zavkhan province area. From the above, it can be said that Zavkhan Province is the land of reincarnated lamas in Mongolia.

What is significant for this present study is that there was a secularized reincarnated ex-lama in Zavkhan who used to be venerated throughout the socialist era. The lama's name is Tserendondov (Figure 2), and he was once recognized as the reincarnation of Milarepa. Milarepa was a famous historical figure in Tibet known for being a rowdy priest and yogi who once committed murder before becoming a priest (Figure 3). Unlike in his previous life, Tserendondov spent his whole life as a diligent local officer of the MPRP.

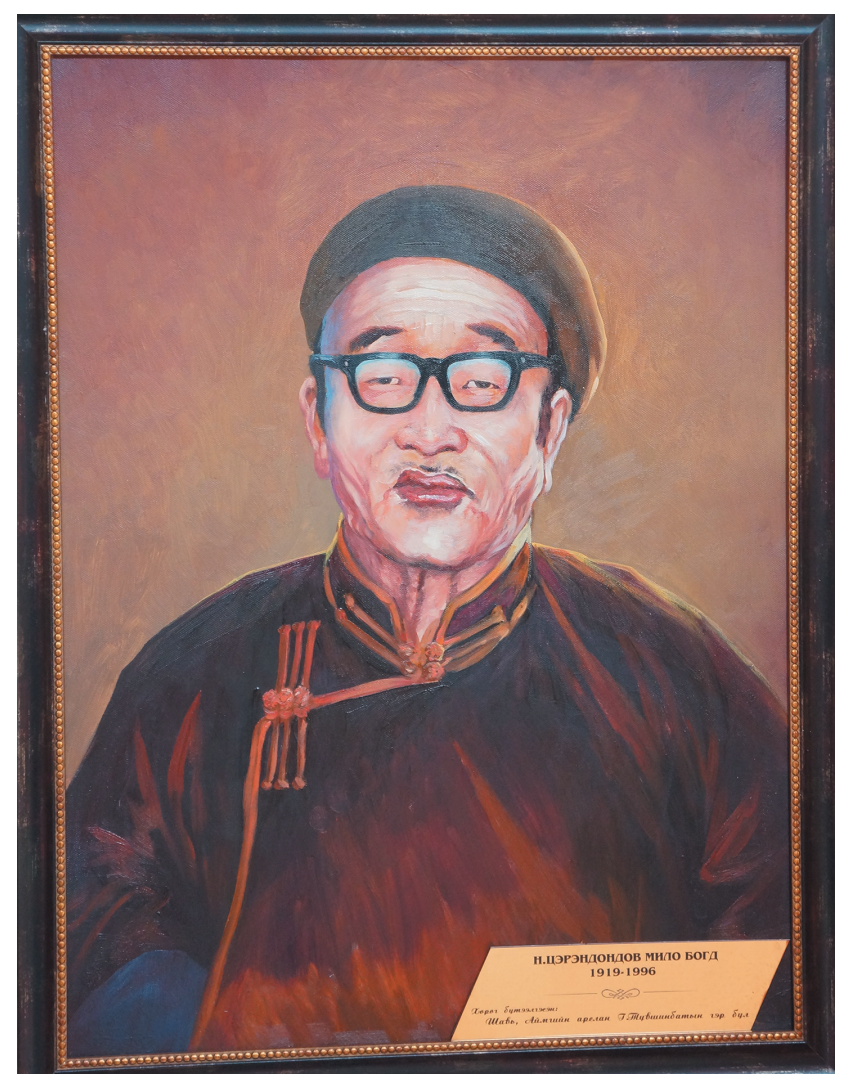

Figure 2: Tserendondov (Miro bogd) Courtesy of Jalkhanz Temple in Uliastai, Zavkhan. 


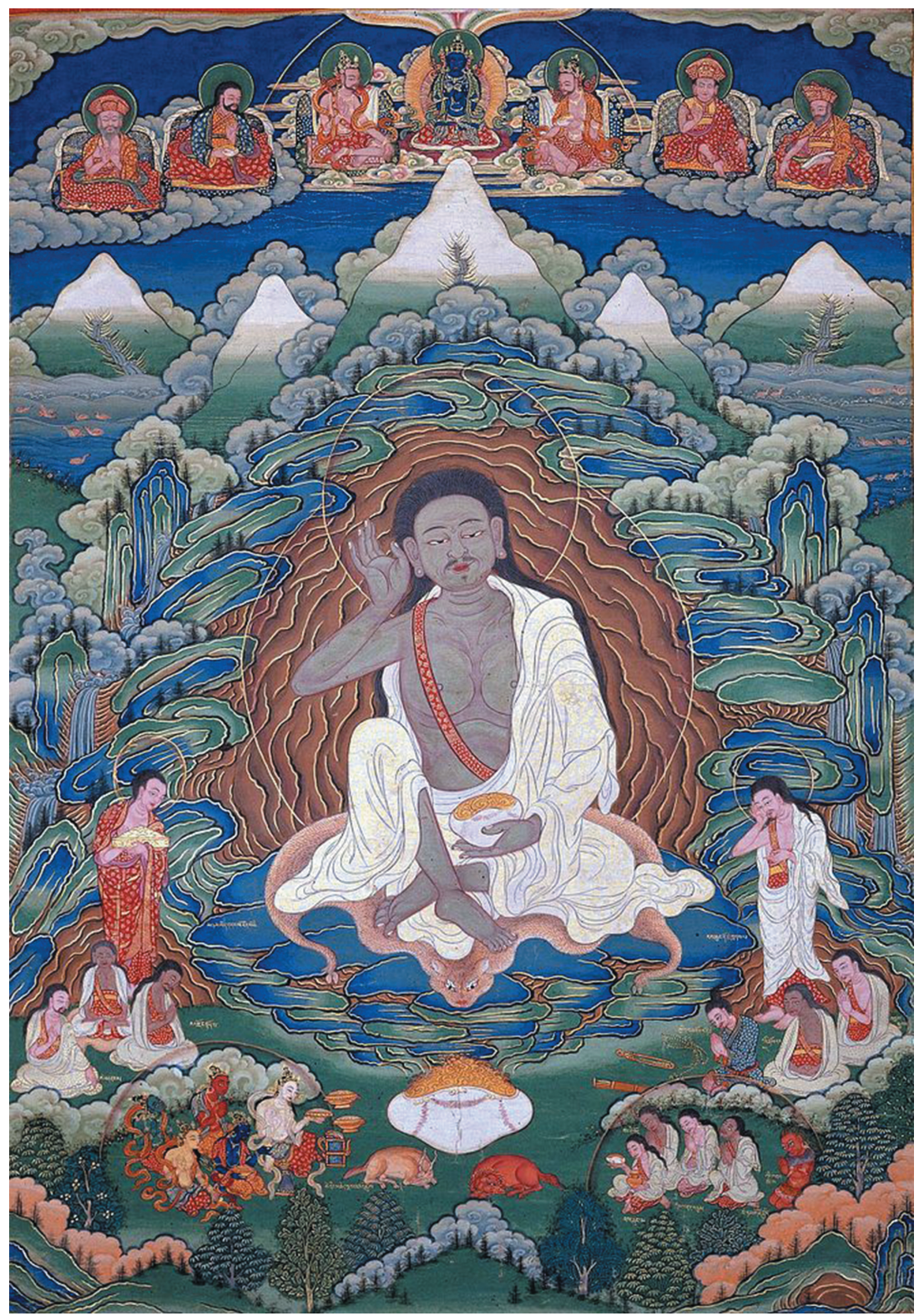

Figure 3: Bhutanese painted thanka of Milarepa, Dhodeydrag Gonpa, Thimphu. Wikipedia (2019) 
Here, I would like to introduce Tsrendondov, or Mongolian Milarepa's life story briefly, quoting a couple of his biographies which were both written by Batsaikhan, a native historian who was very close to the lama. ${ }^{40}$ Before we begin, I should draw to the attention of readers that Batsaikhan's writings have the unique feature of eulogizing Tserendontov throughout the book by mixing and/or confusing his religious deeds and his socialist deeds.

Tserendondov (1919-1996), or Milo bogd (Holy Milarepa) was born in a normal nomad family in Khoshuuch Mergen Beis banner, ${ }^{41}$ or today's Shilüüstei Soum, Zavkhan Province. It was just 5 years before the Mongolian People's Republic was established. According to Batsaikhan, he showed peerless talent (khosgui erdem, literally peerless scholarship) and stopped the rain when he had just started to walk. ${ }^{42}$

At that time, Outer (Khalkh) Mongolia got temporal independence from Manchu Qing shortly after the Xinhai revolution, and established the Bogd Khanate by enthroning the 8th Jebtsundamba as the "holy emperor" or Bogd Khan in 1911. Yet, in 1919, when Miro bogd was born, Mongolia lost its independence again because Chinese troops of the Beiyang government occupied the capital Urga (today's Ulaanbaatar). It was 1924 when the turning point arrived for the nomad boy: Tserendondov was recognized as the 4th reincarnation of Milarepa, by drawing lots from an urn. By a curious coincidence, the Mongolian People's Republic was established in the same year due to the death of Bogd Khan.

It is not clear who decided to carry out a search for the reincarnation of Milarepa, though Batsaikhan proclaimed the "Supreme Holy Priest (Deerkhiin gegeeten)", that is the 13th Dalai Lama, issued a decree to search for the reincarnation. ${ }^{43}$ In any case, Miro Bogd was searched for, recognized, and enthroned under the leadership of the Diluv Khutagtu ${ }^{44}$ in 1924. After the

40 Batsaikhan 2014.

41 Banner is an administrative unit in the Qing Dynasty's era.

42 Batsaikhan 2014: 179.

43 Batsaikhan 2014: 180.

44 However, there is no description of the recognition of Miro Bogd in the biography of Diluv Khutagtu. Quite curiously, usually eloquent Diluv describes the period around Miro Bogd's recognition (1923-1926) in only one paragraph as follows. "In my fortieth year (1923) I again gave up my post at Uliastai. There are many things I do not remember from this period; I had no more official duties of any kind [...]. There were in fact a good many conspiracies, especially ones which took the form of trying to get in touch with the Chinese in various ways. For this reason, I was very careful to restrict myself to religious functions. Even in the old days when people came to ask my advice on political subjects or administrative problems I was reluctant to say anything that would look like meddling in other people's affair's; and now I was especially careful.” (The Diluv Khutagt 2009: 118-119). 
enthronement of the reincarnated lama, Miro Bogd learned Tibetan and Mongolian Buddhist scriptures at Gendenpil monastery, where allegedly over 200 monks were studying at the time, in Otogon Soum (county), Zavkhan. However, his training life at the monastery didn't last long. The socialists were making threatening moves against the Buddhist institutions, the MPRP started to confiscate monasteries' assets, and many monks were compelled to secularize. Miro Bogd finally decided to secularize, and became an animal herder in order to protect himself from religious oppression around 1930, following the advice of his father. ${ }^{45}$

In 1933, he got employed as a messenger boy (ulaach) at a supply point in the national transportation system. Yet, getting a secular job was not good enough for this ex-reincarnated lama to be protected from life-threatening danger posed by the communists. That's why he voluntarily joined the army in 1939 in accordance with his uncle who was also a secularized monk, and was assigned to the 6th division of the National Army at Southern Govi. Working at a place for away from his homeland allowed him to conceal his status of exreincarnated lama. He was assiduous enough to learn Cyrillic script using spare time when he served in the army. Surprisingly enough, he got permission to join the MPRP in December of 1943 because his job performance was highly evaluated: "he was loyal to the government policy and served in the army very faithfully."46

After the end of World War II , he was discharged from the army, and finally came back home to Zavkhan. He got a position in the Shilüüstei Soum government as a teacher of the Mongolian new script, and a director of the daily food workshop because he was familiar with Cyrillic new Mongolian script, which was introduced in 1946 by abolishing traditional Mongolian script. In 1949, Tserendondov got promoted to "agent", the distributor of the trade and material collection service (khudaldaa, beltgeliin agent [a:gient]) in the Shilüüstei Soum. His duties at work were, in the first place, to distribute to local herders' commodities and foodstuffs like sugar, candy, tea, and flour which were produced in the city, and second, to collect livestock products such as dairy foods and fur from herders.

He served for over 40 years as the "agent", and that's why he was nicknamed as "agent guai” or "Mr. Agent” by local people in Shilüüstei Soum. From 1958 to 1976 he also worked as a member of the Shilüüstei County Assembly, Zavkhan Province. In 1985, he was awarded the Champion Agent of the Trade and Material Collection Service in Zavkhan (aimgiin avraga agant), and finally he

45 Batsaikhan 2014: 183-184.

46 Batsaikhan 2014: 188. 
was bestowed the National Polaris Order (altan gadas odon) due to his life-long contribution to local society. ${ }^{47}$

As described above, Tserendondov seemingly led an exemplary life as an MRRP local cadre. Batsaikhan, Agent guai's biographer, proudly described his detailed "meritorious" deeds, and applauded him as a "very hard-worker", 48 "the exemplary person in western Mongolia who contributed to construct the new society", ${ }^{49}$ and "the notable figure with paramount judgement". ${ }^{50}$ In other words, the figure of Miro Bogd described by Batsaikhan is in sharp contrast in character and behavior to the original Tibetan legendary magical yogi Milarepa, flying in the sky, practicing sorcery to kill many people, and finally practicing solitary meditation in caves in order to purify his bad karma.

It would appear that Batsaikhan's understanding of the ex-reincarnated lama is somehow confused, because Miro bogd seems to be praised not because of his magico-religious ability but because of his excellence as a temporal leader. The author is a pious Buddhist, and socialist as well. It can be explained by the notion of Ngo and Quijada referred to above, an "intimately intertwined situation of religious and political imageries in the communist/post-communist world". ${ }^{51}$ Even so, what was happening with regard to the magical practices in the socialist era? How could Miro bogd practice magic as a diligent member of the socialist party, then?

\section{4 “Magical Practices" by Mr. Agent under the socialist regime}

Quite curiously, my fieldwork in Zavkhan shows that apparently Tserendondov (aka Miro bogd/ Mr. Agent) practiced magic spontaneously. He did so not on his own initiative but in response to the request of local people who asked him to practice magic-like deeds, for example, asking him to give Tibetan names to newly-born children.

In September 2016 I conducted fieldwork about the ovoo (stone heaps used as shrines) ceremony, which Miro Bogd created when he was alive, and took place in Silüüstei Soum, Zavkhan. The grassland around the ovoo was crowded

47 Batsaikhan 2014: 190-197.

48 Batsaikhan 2014: 191.

49 Batsaikhan 2014: 195.

50 Batsaikhan 2014: 195.

51 Ngo / Quijada 2015: 2. 
with local people; almost all the people in this county seemed to have flocked to this area in order to take part in the ceremony of Miro Bogd's ovoo. There was an altar near the ovoo, and several monks were chanting sutras, and then people started going around the ovoo in order to venerate it. Naadam Festival was also held near the ovoo: Mongolian wrestling, Mongolian archery games, and horse riding races were held commemorating Miro Bogd's deeds. Including the ovoo festival, I spent about 10 days conducting fieldwork in Zavkhan.

When I asked some elders who came to the ovoo ceremony, all of them admired "Mr. Agent/Miro Bogd", because local people said they would go to ask his advice, and get the right answer. Surprisingly enough, they answered without exception that they all had gotten their names from him. In fact, all of the elders who I encountered there had Tibetan names. Giving peculiar names in Tibetan used to be and still is vital for Mongols in order to avoid misfortune such as disease and death so that it is not simply a temporal deed but highly magical.

Second, local people understood Tserendondov's government delivery work as magical behavior. For instance, an old man in his 70's recollected the old times and spoke as follows.

"Mr. Agent was a very quiet person. When a local child was sick, he would give him or her lumps of cube-sugar, and said, 'Just eat it' when he delivered groceries and commodities. Surprisingly, the child used to get well soon after taking the sugar!" Another elder told me that he also used to get some cubesugar when Mr. Agent distributed groceries and commodities, and would say "You need to take a lump of cube-sugar each day because you are sick, and you will get better." So, apparently Tserendondov used to heal people by "prescribing” cube-sugar. However, we must remember cube-sugar was, like vegetables, first brought to Mongolian nomads by Russians under socialist modernization. Hence, sweet cube-sugar must have worked effectively for Mongols at that time as an energy drink, medicine for recovering from fatigue, or even a cold remedy, because they had rarely taken saccharides before modernization. What is also important is that such an "energy booster" like sugar was brought by an exreincarnated lama, so that even a placebo effect could be expected.

Nonetheless, it was still unclear whether Tserendondov healed people by using knowledge of modern nutrition, or using the magico-religious methodology of Tibeto-Mongolian Buddhism. Therefore, I held further interviews with local people, and finally acquired crucial information from Mr. B (44 years old), who was Tserendondov's nephew (his brother's son), and Ms. D (64 years old), a woman who was a distant relative of his. According to Mr. B, Tserendondov also used to give people arts (dry juniper powder) and rashaan (holy water), as well. Juniper powder is used for Buddhist rituals by burning it as incense. Holy water, which is mixed water and juniper powder, is also used for Buddhist rituals, and 
usually monks made and gave it to followers. Undoubtedly, this anecdote shows Tserendondov carried out magical practices intentionally. Ms. D's following remarks also support the evidence of magical practice by Tserendondov:

What Mr. Agent would give us was only cube-sugar and juniper powder. When I was a child, my parents and I went to Mr. Agent's house asking advice because our düü (younger sibling $)^{52}$ often collapsed at that time. He tried to take sugars from the chest but couldn't, so he grasped some cube-sugars from a box inside the cauldron, and gave them to me after breathing strongly on them.

In Mongolia, breathing on something is a typical magical behavior for Buddhist monks and shamans: it is generally believed that some kind of supernatural power will be poured into the object on which a monk or shaman breathes. Furthermore, Ms. D also attested that Mr. Agent kept a Buddhist rosary even in the socialist time. But she said he never brought it when he went outside.

Tserendondov's magical practice was not limited to only cube-sugar healing but also expanded to include "yum khelj ögökh", or making predictions. Ms. D told me one more episode of Tserendondov's "miraculous (gaikhaltai) ${ }^{53}$ deeds" when I asked her how Miro Bogd made predictions (yum khelj ögökh).

\footnotetext{
It was around 1984-1985 when our grandfather passed away. My grandmother absolutely lost her mind because she was left with 8 children after his death. At that time, people would never go see a doctor. Local clinics and hospitals didn't treat mental disorders. What's more, the only hospital we used to go to was the provincial hospital in Khovd. But, Miro-bogd said to us, 'Don't send her to Khovd. Just keep her home for the time being.' One morning, Miro Bogd called the oldest son of my grandmother, and said, 'Go to Ulaanbaatar with your mom, and hospitalize her in the hospital named Sharkhad.' Then, he arranged to get two air-tickets to Ulaanbaatar for them. Finally, our grandmother got well, after being hospitalized at Sharkhad for a week.
}

Presumably, Ms.D interpreted Tserendondov's advice and support as “miraculous". However, it can be said that Tserendondov's advice and support in this case was quite appropriate and rational, resembling that carried out by social workers today, and that he knew Sharkhad was the only mental hospital in Mongolia during the Socialist era. Moreover, he had a great deal of influence to get the air-tickets for them in the Socialist time when travel was strictly restricted. Yet, his advice and arrangement was understood by Ms. D as the lama’s "miraculous deed."

52 Mongolian words “düü" means both younger brother and younger sister (Bawden 1997: 141). 53 Actually the Mongolian word gaikhaltai which I translated as "miraculous" connotates both religious and non-religious 'Surprising', 'strange', and 'amazing' (Bawden 1997: 86). It is not an exclusively religious concept. 
I came across another narrative in which a temporal deed by Tserendondov was interpreted as magical practice. Ms. C (68 years old), a niece of Tserendondov and raised by him, told me about his healing methodology. When I asked her whether or not he would give baria zasal (Mongolian traditional massage and bone-setting) to local people, she answered as follows.

He didn't give baria zasal at all. He would only tell people what they should do in order to get better quickly. For example, 'Go see that doctor!' or "See that bariach (traditional masseuse/massager and bonesetter)!' Then, he or she would really get better.

As we see from her narrative, Tserendondov supported people just like social workers usually do. Nonetheless, his advice seemed to be interpreted as a miraculous or amazing ability (gaikhaltai chadal). In other words, basic knowledge of modern medical care might have been interpreted as miracles by local people.

Also, Ms. D told me another odd story in which apparently she might have understood Tserendondov's professional ability on rationing goods as the supernatural power of a reincarnated lama;

Since he was the agent of the county, he used to send someone to pick up groceries which were provided from the province. But no one would steal from the groceries on the way to Shilüüstei Soum. If it rarely happened, that guy would always confess to him (Mr. Agent) finally. The goods which the province provided were cotton cloth for deel (Mongolian traditional tunic), sugar, flour, rice, tea, and so on. He was so loyal to the party and the government that all the provincial officials and Soum's officials would treat him with favor. They even came to him secretly, asking him to tell fortunes. That's why even some people from Buryatia visited here to make a condolence call when he passed away. Since we have venerated and believed (shütej bishirdeg baisan) such a miraculous and wonderful person (gaikhaltai mundag khün) like him, you know, we don’t regard current reincarnated lamas so highly.

In the testimony above, Tserendondov's ability and achievement concern distinctly administrative things rather than religious things. However, what is remarkable here is that Ms. D admired Tserendondov's administrative ability comparing it with current reincarnated lamas' magico-religious power. In short, here, administrative and religious ability are regarded as equal by local people. Regarding administrative ability in socialist times, Caroline Humphrey gave us a very insightful discussion in her monograph on Korkhoz in Buryatia, Russia. According to Humphrey, collective farms frequently carried out a certain amount of production which was extra to the plan, and such surplus was called "clear income" (ru. chistii dokhod) because it would never go back to the state and/or go towards the reproduction of the Korkhoz economy. Hence, "clear income" was essential for the local socialist economy because, for collective farms, it could be "manipulable resources" in order to, first, negotiate with the rion, or 
local district government, about setting plans and norms, and second, sell its surplus outside the rion at the highest price available. In short, Humphrey clarified how informal social relationships had been constructed in the socialist era, focusing on the barter trade of manipulable resources coming from the surplus dubbed "clear income". ${ }^{54}$ If we apply this discussion to Mongolia, it is predictable that Tserendondov might have demonstrated his ability to local people, using "manipulable resources". What is more important is that, for local people, his elaborate administrative ability overlapped with a kind of magico-religious characteristic of a reincarnated lama. The following narrative by a middle aged woman in her forties also shows Tserendondov's overlapping image as a religious and administrative character:

All of us venerated Mr. Agent. The foodstuffs like flour and sugar which were brought by Mr. Agent were special for us. People loved to buy them because they felt 'these are provided to us after Mr. Agent chanted a spell (tarin) on them' or, 'these goods have magical power (ubidastai).'

Her husband (44 years old) also added:

Some people who knew the "secret" would buy sugar and rice in bulk, bringing containers, and preserve them in their house at that time. Mr. Agent prayed for the happiness of people, providing just spell-enchanted sugar and rice.

Here, it can be confirmed that Tserendondov's distribution work was also received as magical practice. Oddly enough, people strongly believed Mr Agent recited a spell on sugar and rice before he provided them, despite most of them never witnessing that he actually did so. In other words, local people's memory that he was once a reincarnated lama might automatically have made them understand his distributing of goods as a kind of magical practice, or Buddhist ritual.

Mr Agent was also well known for predicting the future. Local people told me he used to advise herders on where to move in their seasonal migration. Ms $\mathrm{C}$, a niece of his, also told the following episode:

He didn’t speak clearly about the future. He just suggested (about the future), inserting information like this. 'By the way, this year will be great. Livestock will increase very much,' or 'Well, maybe we need to prepare for the severe winter.' Only a serious guy can understand what he means. A man who had grown up in Socialist times would never say directly, 'Oh, watch out! Something like this or that will happen to you!' Anyway, he helped local people like this.

54 Humphrey 1998: 221-227. 


\section{Interpreting Socialist Modernity into Magic}

So far I have shown the actual instances of Mongols' practices which locate in between the religious and the secular by examining Buddhist practices in Zavkhan Province where people maintained strong worship for reincarnated lamas "secretly" during the socialist era. However, before concluding this paper, we need to re-think, does the magicalization of socialism merely mean a widely observable interpretation of socialist modernity as magic because we didn't demonstrate this case is specific to only Mongolia.

Anthony Vanchu, who studies Russian modern literature, argues the odd relationship between socialist modernity and magical thinking in early Soviet days by examining the novel Rodina Elektrichestva (The Birthplace of Electricity) by Andrei Platonov, saying "in fact, the occult proved a curiously palpable presence in early Soviet culture. (...) For the plastoi narod (simple people), science became a magical means not just to realize distant hopes but also to meet the most basic human needs". 55 The protagonist of Rodina Elektrichestva is a nameless roving engineer who assembles the materials to construct an electric pump and irrigate the parched field of the backwater village of Verchovka. Finally, the common people in the novel end up perceiving the science and technology that the engineer brings to them as a means of channeling supernatural forces to work on their behalf, something they have attempted before" ${ }^{56}$

This case shows the magicalization of modernity could happen even in the process of socialist modernization anywhere. Agreeing with Wittgenstein, Hamamoto asserts magical practices can best be characterized not as subscribing to the incorrect theory but abandoning the search for the evidence/reason. In this sense, it can be said both socialist dogmatism and modern technology might have strong affinity with magic. However, I would like here to highlight that, whereas in the Russian case modern technology was directly interpreted as magic by common people, in Mongolia, modernization was interpreted as magic via a secularized lama. In other words, the magicalization process was interactive between lay people and the ex-reincarnated lama, unlike it being a one-way process from lay people in Russia.

It is highly probable that Tserendondov, the Mongolian Milarepa, used socialist modernity for his "Buddhist" practice, because he kept his religious scripts and equipment secretly in his house. One of his nephews showed me his belongings which had been concealed in his closet (avdar), and it includes some sutras, thanka

55 Vanchu 1997: 202-204.

56 Vanchu 1997: 206-209. 
paintings, vajiras, an urn, and so on. Also, the nephew told me he used to chant sutras in his home when he was alive. If so, it can be said that Tserendondov had never abandoned his faith, rather, he purposely made magical practices in order to "preserve” Buddhism, using his government position of "agent".

Apparently it was not only Tserendondov who practiced Buddhism using the socialist regime. According to the National History compiled in Socialist times, "collecting their horses and the arms, the rebels in Jalkhanz Monastery (in Zavkhan) wittingly made Buddhist monks secularized en masse. Then, they intentionally made secularized monks to take employment tests, and made them join the party, administrative organizations, the army, local schools. [...] They used such a cunning way". 57

In short, Buddhist monks could survive through the tactic of disguising/identifying $^{58}$ themselves as non-religious citizens. More precisely, deprived of their monastic institution, religious scripts, equipment, and robes, Buddhist monks became de facto popular magico-religious practitioners. In this sense, it can be said that the function of secularized monks was quite similar to that of shamans. Indeed, I heard people in Mongolia used to go asking advice from a "person who knows something (yum meddeg khün)": This was actually a term of argot or secret language in the socialist era, referring to people like ex-monks, ex-shamans, and fortune-tellers. This socialistic rhetoric establishes that Buddhist monks, shamans, and fortune-tellers were sometimes placed into the same category in socialist Mongolia. ${ }^{59}$

It was Caroline Humphrey who first pointed out the strong affinity between shamanism and socialism. According to her, depending on the Soviet social system itself, shamanism could survive because it is fluid, undogmatic, secret, and transient unlike Soviet socialism and Buddhist institutions, and what is most important, shamanism provides mainly explanation of suffering which the communist party never does: they mostly take up more positive issues such as the value of labor, productivity, and so on. That's why shamanism could function in a compensatory role to the party. Humphrey called such shamans in the socialist era the "bricoleur of the Soviet world." 60

57 Shirendev et al. 1969: 290.

58 Through spending significant time with Mongols, I understand whether they disguise or identify themselves as socialist is unclear and vague because not clearly defining black and white is essential for survival in the socialist society with an atheistic yet religious atmosphere. That's why I describe their attitude as 'disguise/identify'.

59 However, this might not be an entirely new phenomenon, as Humphrey pointed out (Humphrey 1998: 550), because several people, those who were called $d z o c h i$, were both shamans and lamas at the same time (Mikhailov 1979:133; Humphrey 1998: 416).

60 Humphrey 1998: 415-417. 
However, the role of the secularized reincarnated lama in Mongolia which I depicted here in this paper is essentially different from that of shamans in Buryatia: Tserendondov by no means functioned to compensate the Soviet social system, nor to explain the cause of misfortune and suffering. Rather, his role overlapped with the exemplary model of socialist ideology. At root, Mahayana Buddhism is somehow similar with socialism in terms of proclaiming the idea of social relief: no matter whether we describe Tserendondov's deed as "Comrade Tserendondov showed remarkable performance on constructing socialist society, providing people healthy and nourishing foods ... " or "the Miro bogd relieved all living beings who suffers from dukka of hunger," the phenomena which happened in their local society can be considered almost the same. In this respect, it can be said that Buddhism and socialism share the grand narratives of "social relief". On the contrary, we can suggest that shamanists have never created such a big story: what they have always treated is the symptoms of the problem, not the cause; they have provided temporary expedient. Despite the fact that the whole religious institution had almost been destroyed, Buddhist monks could survive throughout the socialist era, disguising/identifying themselves as socialists, overlapping Buddhist teaching with socialist ideology, and magicalizing socialist modernity, as well.

That is why it has been, and still remains, quite common in Shilüüstei Soum for a picture of Tserendondov to be displayed on the chest (avdar) at the rear part of the house (khoimor), where thanka-paintings of Buddhist dieties and small Buddhist statues were displayed before the premodern era because he has been venerated for a long time. An elder told me that in the 1980's, when a reporter came to Shilüüstei Soum, he was very surprised that all the households displayed a picture of Tserendondov on their chests, as if they were displaying Buddha's paintings on the altars. Then, he informed the MPRP, saying "locals in Shilüüstei Soum are idolizing, and worshiping a specific person.” However, although an investigator of the MPRP came from Ulaanbaatar, he had no option but to tolerate the practice because local people answered, "We admire Mr. Agent just because he was awarded as the best agent in our province!” This episode shows that Tserendondov could disguise/identify himself with the socialist regime very well so that people accepted his personality and actions.

Presumably Tserendondov himself couldn't distinguish/separate his socialist self and Buddhist self clearly, because what he practiced in everyday life was both socialistic and Buddhistic. That is why some people said that what he always gave them were sugar and juniper: sugar is a commodity which was brought to rural Mongols by socialist modernity, and juniper powder is a stuff which Buddhist monks traditionally used when they conducted rituals. He must have known both of them "work" very effectively for his people. Sugar and 
juniper are, in short, symbol for his dual identity of Buddhist and Socialist. In any case, he represented both Socialism and Buddhism in a Mongolian local society by practicing miraculous magic, such as healing with sugar and amazing advice, making weather predictions, giving Tibetan names to new born children, showing wonderful administrative ability, and so on.

Moreover, it is not only Tserendondov's case in which socialist ideology and Buddhism overlapped, but it seems to have been a universal phenomenon in Mongolia because a large number of ex-Buddhist monks worked as administrative officials, artisans, and school teachers after their secularization. Especially, as previously argued, school teachers were highly respected because they were bagsh, which corresponds to teacher and guru as well. Those who were called bagsh in the socialist era, regardless of not being real school teachers, made magico-religious practices for local people as a bagsh = guru, as before socialist modernization: giving Tibetan names to newly-born children, conducting funerals, telling fortunes, and so on.

\section{Conclusion}

In this paper, I have explored the "magicalization of socialism" by examining the "Buddhist practice" of an ex-reincarnated lama and local people he lived with in Mongolia. Did socialism really enhance magical practices and ideas in people's everyday life, instead of expelling religion? In Ulaanbaatar, whereas the Buddhist monastery and the MPRP constructed a subtle mutual dependence relationship after 1944, which I have called Buddified Socialism and Socialized Buddhism, in a local area like Zavkhan, the field data shows that magical practices could survive in their everyday life by re-interpreting ex-reincarnated lama's temporal deeds and utterances, which were mostly derived from socialist modernity, as "magical" practice. This might be because socialism could have expelled the four major institutional constituents of religion - clergy, religious scriptures, church/temples, and public rituals - from the social space. Socialist modernity was interpreted as magic, and such magic had been enhanced throughout the socialist era because there was neither a way nor a will to abandon it. This magic worked interactively between ex-Buddhist monks and common citizens as described below:

1. An ex-reincarnated lama used modern technology brought by socialism as the magical rite of Buddhism

2. Local people accepted modernity brought by socialism as the magic/miracle of the ex-reincarnated lama/ Buddhism. 
In addition, socialistic magic worked very well both in public and private spheres: People interpreted socialist modernity as magic in the public sphere, and also believed that ex-monks chant magical spells, or mantra secretly in the private sphere.

Anthropologists have clarified that modernization, especially as brought by Capitalism, has by no means annihilated "irrational thinking" such as magic or witchcraft or other occult practices; rather, it has enhanced them. ${ }^{61}$ On the contrary, in this paper, what I have explored and examined is the relationship between socialist modernity and magical practices. The enhancement of magic by socialist modernity is different from capitalist modernity in terms of discontinuity with pre-modern tradition: by expelling institutional constituents of religion (clergy, religious scriptures, church/temples, and public rituals), brand-new modern technology and modern knowledge have been connected with magical thinking. In this sense, whereas magic practice made by socialism is inherited in the post-socialist era, the traditional practices of institutional religions were extremely cut off by socialism. In other words, only by specializing in magical practices mixed with modern technology and knowledge, could institutional religion survive under the socialist regime.

This is the religious continuity between socialism and post-socialism, and that's why people in post-socialist countries have strong affinity with magic, shamanism, occultism, and supernatural things. In other words, the bloom of magic cultures in post-socialism is the authentic cultural heritage of socialism. Another important point is that magic was practiced not only as the explanation of misfortune, but also an explanation of fortune which is brought by socialism. People don't necessarily embrace negative images of socialism, rather they embrace positive memories of "miraculous" deeds of socialist modernity. That's why they sometimes are religious but socialistic at the same time. Therefore it is quite natural for post-socialist Mongolians that Zawa damidin Rinpoche gained his prominence because he has such magical power to make people rich, and at the same time he dismantled the statue of D. Sükhbaatar, the revolutionary hero of early twentieth century, from Ulaanbaatar, and relocated it to Rinpoche's temple in Dundgovi (Figure 4), saying Sükhbaatar was not only a socialist hero but also a great man who created the political independence of Mongolia so that we should venerate/worship (shütekh yostoi) him. In short,

61 Mcfalane 1999; Comaroff/Comaroff 1993; Geschire 1997; Oda 2007; Kondo 2009. 


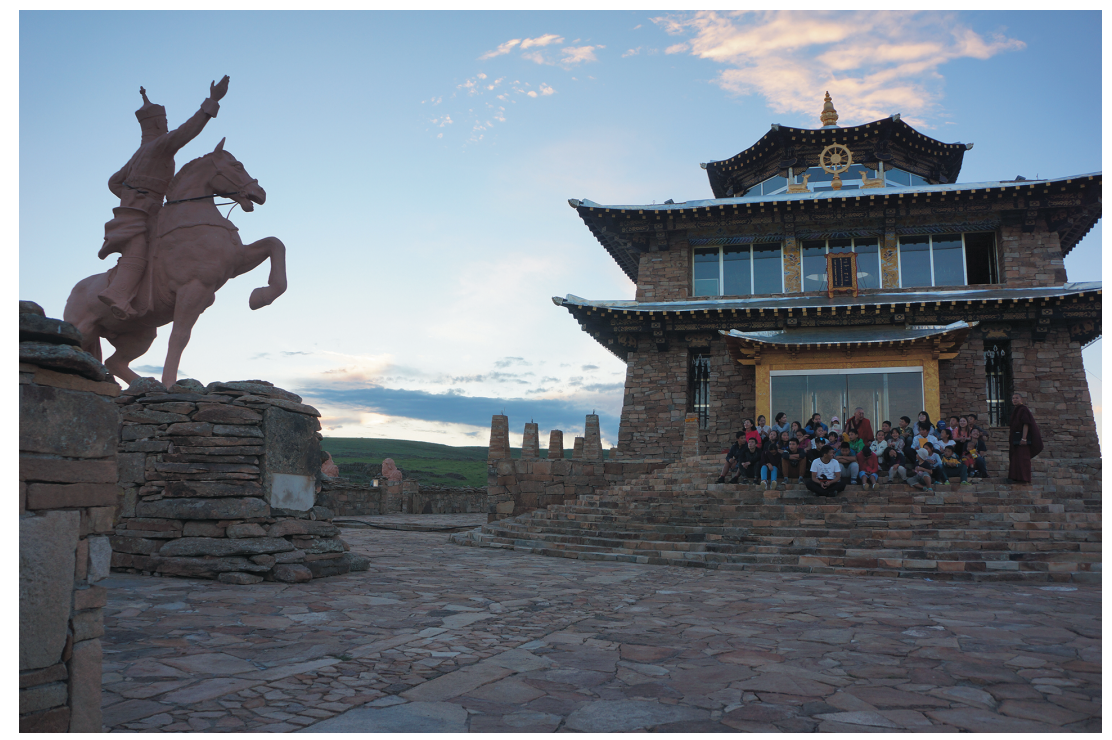

Figure 4: The statue of D. Sükhbaatar at Zawa Damidin Rinpoche's temple in Dundgovi.

socialism was so magical that it could affect people even after its collapse 30 years in the past.

Funding: This work was supported by JSPS KAKENHI (A) Grant Number 16H02719, entitled "The Interdisciplinary Research on the Glocal Practices of Mongolian Buddhism” (P.I. Ippei Shimamura).

\section{Bibliography}

Asad, Talal (2003): Formation of the Secular: Christianity, Islam, Modernity. Stanford: Stanford University Press.

Balzer, Majorie Mandelstam (2011): Shamans, Spirituality, and Cultural Revitalization: Explorations in Siberia and Beyond. New York: Palgrave Macmillan.

Batsaikhan, P. (2014): Gegeen Khuvilgaadyn Aman Tsadig (The Oral History of Holy Reincarnated Lamas). Ulaanbaatar: Mönkhiin Üseg.

Bawden, Charles R. (1997): Mongolian-English Dictionary. London: Kegan Paul International. Bennigsen, Alexandre (1989): “Islam in Retrospect”. Central Asian Survey 8.1: 89-109.

Bernstein, Anya (2013): Religious Body Politics: Rituals of Sovereignty in Buryat Buddhism. Chicago and London: The University of Chicago Press.

Buyandelger, Manduhai (2013): Tragic Spirits: Shamanism, Memory, and Gender in Contemporary Mongolia. Chicago: University of Chicago Press. 
Casanova, Jose (1994): Public Religion in the Modern World. Chicago and London: University of Chicago Press.

Comaroff, J. / Comaroff, J. L. (1993): “Introduction”. In: Modernity and Its Malcontents: Ritual and Power in Postcolonial Africa. Edited by J. Comaroff and J. L. Comaroff. Chicago: University of Chicago Press, I -XXXV II.

Dashbadrakh, D. (2004): Mongolyn Khutagtuudyn Namtryn Oillogo: XVII-XX zunn. (The Chronicle of Mongolian reincarnated lasmas: From 17th century to 20th century). Ulaanbaatar: Shinjlekh Ukhaan Akademi Tüükhiin Khüreelen (Institute of History, Mongoloan Academy of Sciences).

The Diluv Khutagt (2009): The Diluv Khutagt of Mongolia-Political Memoirs and Autobiography of $A$ Buddhist Reincarnation Translated by Owen Lattimore and Fujiko Isono. Ulaanbaatar: Polar Star Books.

Durkheim, David Émile (2001 [1912]): The Elementary Forms of the Religious Life Translated by Carol Cosman. Oxford: Oxford University Press.

Frazer, James George , Sir (1998 [1890]): The Golden Bough: A Study in Magic and Religion. Oxford: Oxford University Press.

Fujiwara, Junko 藤原潤子 (2010): Norowareta Natasha-Gendai rosia ni okeru jujutsu no Minzokushi 呪われたナターシャ：現代ロシアにおける呪術の民族誌 (Cursed Natasha: An ethnography of magic in contemporary Russia). Kyoto: Jinbun-shoin 人文書院. Geschire, Peter (1997): The Modernity of Witchcraft: Politics and the Occult in Postcolonial Africa. Charlottesville: University of Virginia Press.

Grishaeva, Ekaterina/ Shumkova, Valeria (2017): "What does it mean to be a true orthodox in post-secular Russia: Attitude toward magic among orthodox believers in the middle ural". In: Religion and Magic in Socialist and Post-Socialist Contexts 1: Historic and Ethnographic Case Studies of Orthodoxy, Heterodoxy, and Alternative Spirituality. Edited by Alexsandra Cotofana and James M. Nice. Ibidem-Verlag: Stuttgart, 51-74.

Hamamoto, Mitsuru 浜本満 (1997): “Jujutsu-jujtsu ha gijutsu ka shōchō ka 呪術一呪術は技術か 象徵か (Is magic technology or symbolism?)”. In: Bunka jinruigaku kīwādo 文化人類学 キーワード. Edited by Shinji Yamashita 山下晋司 and Takeo Funabiki 船曳健夫. Tokyo: Yuuhikaku 有斐閣, 108-109.

Hangartner, Judith (2011): The Constitution and Contestation of Darhad Shamans' Power in Contemporary Mongolia. Leiden: Global Oriental.

Hann, Chris (2000): "Problem with the (De)privatization of Religion". Anthropology Today 16.6: 14-20.

Hann, Chris, M. (ed.) (2010): Religion, Identity, PostSocialism. Halle/Saale: Max Planck Institute for Social Anthropology.

Havnevik, Hanna (2017): "Buddhist Modernity and New-Age Spirituality in Contemporary Mongolia”. In: Buddhist Modernities: Re-Inventing Tradition in the Globalizing Modern World. Edited by Hanna Havnevik, Vladimir Tikhonov and Koen Wallens. New York/London: Routledge, 115-132.

Humphrey, Caroline (1998): Marx Went Away - But Karl Stayed Behind. Ann Arbor: The University of Michigan Press.

Juergensmeyer, Mark (1993): The New Cold War?: Religious Nationalism Confronts the Secular State. Berkley: University of California Press.

Kollmar-Paulenz, Karénina (2003): “Buddhism in Mongolia after 1990”. Journal of Global Buddhism 4: 18-34. 
Kondo, Hidetoshi 近藤英俊 (2009): “Purorōgu shunkan wo ikiru ko no nazo, nazomeku Afurika gendai プロローグ 瞬間を生きる個の謎、謎めくアフリカ現代 (Prologue: The enigma of individuals who live in the present moment, or mysterious African modernity)". In: Jujutsuka suru modaniti: Gendai Afurika no shūkyō jissen kara 呪術化するモダニティー現 代アフリカの宗教実践から (Modernized Modernity: the religious practices in Contemporary Africa). Edited by Toshiharu Abe 阿部年晴, Makoto Oda 小田亮 and Kondō 近藤英俊 Hidetoshi. Tokyo: Fūkyōsha, 17-109.

Lewis, David. C. (2000): After Atheism: Religion and Ethnicity in Russia and Central Asia. Richmond Surrey: Curzon Press.

Lindquist, Galina (2006): Conjuring Hope: Healing and Magic in Contemporary Russia. New York: Berghahn Books.

Lkhagvademchig, Jadambiin. (2018): "Double Headed Mongolian Buddhism - A Historical and Anthropological Study on Identity Politics inside the Mongolian Buddhist Institution". Doctoral Thesis, Hikone: The University of Shiga Prefecture.

Luckmann, Thomas (1967): The Invisible Religion: the Problem of Religion in Modern Society. New York: The Macmilan Company.

Luvsanvandan (1977): “Madkh'yamaka khemeekh Dundad Üzel” (On the Middle Way Named 'Madkh'yamaka'). Filosofi Erkhiin Sudlal (The Study of Great Scholars of Philosophy) 1.10: 83-92.

Macfalane, Alan (1999): Witchcraft in Tudor and Stuart England: A Regional and Comparative Study. London: Routledge.

McMahan, David, L. (2008): The Making of Modern Buddhism. New York: Oxford University Press.

McMahan, David, L. (ed.) (2012): Buddhism in the Modern World. Abingdon: Routledge.

Menzel, Birgit (2007): "The Occult Revival in Russia Today and Its Impact on Literature". The Harriman Review 16.1: 1-14.

Mikhailov, T. M. (1979): "Vlianiye lamaizma i Khristiyanstva na Shamanizma Buryat" (The Influence of Lamaism and Chrisitianity on the Shamanism of the Buryat). In: Khristianstvo $i$ Lamaizm u Korennogo naseleniya Sibirii: vtoraia polovina XIX - nach. XXv (Christianity and Lamaism in the Native Population of Siberia: From the latter half of the nineteenth century to the beginning of the twentieth century). Edited by I. S. Vdovin. Leningrad: Nauka.

Miner, Steven Merritt (2003): Stalin's Holy War: Religion, Nationalism, and Alliance Politics 1941-1945. Chapel Hill: University of North Carolina Press.

Ngo, Tam T.T. / Quijada, Justine B. (eds.) (2015): Atheist Secularism and Its Discontents: A Comparative Study of Religion and Communism in Eurasia. Basingstoke: Palgrave Macmillan.

Oda, Makoto 小田亮 (2007): “Maegaki まえがき” (Foreword)”. In: Jujutsuka suru modaniti: Gendai Afurika no shūkyō jissen kara 呪術化するモダニティー現代アフリカの宗教実践から (Modernized Modernity: the religious practices in Contemporary Africa). Edited by Toshiharu Abe 阿部年晴, Makoto Oda 小田亮 and Hidetoshi Kondō 近藤英俊. Tokyo: Fūkyōsha, 1-9.

Pedersen, Morten Axel. (2011): Not Quite Shamans: Spirit Worlds and Political Lives in Nothern Mongolia. Ithaca and London: Cornell University Press.

Pelkmans, Mathijs (ed.) (2009): Conversion after Socialism: Disruptions, Modernisms and Technologies of Faith in the Former Soviet Union. New York and Oxford: Berghahn books.

Pollack, Detlef (2003): "Religiousness inside and outside the Church in Selected PostCommunist Countries of Central and Eastern Europe". Social Campas 50.3: 321-334. 
Pozdneev, Aleksei Matveevich (1993 [1887]): Ocherki byta buddiiskikh monastyrei i buddiiskogo dukhovenstva $v$ Mongolii $v$ sviazi s otnosheniiami sego poslednnego k narodu. (Religion and ritual in society: Lamaist Buddhism in late 19th-century Mongolia). Elista, Russia: Kalmytskoe KN. Izd-vo.

Shimamura, Ippei (2002): "The roots-seeking movement among the Aga-Buryats: New lights on their Shamanism, history of suffering, and diaspora". In: Mongolian Culture Studies IV - A People Divided: Buriyat Mongols in Russia, Mongolia and China. Edited by Yuki Konagaya. Cologne, Germany: International Society for the Study of the Culture and Economy of the Ordos Mongols (OMS E.V.), 88-110.

Shimamura, Ippei (2004): “The Movement for Reconstructing Identity through Shamanism: A Case Study of the Aga-Buryats in Post-Socialist Mongolia". Inner Asia 6.2: 197-214.

Shimamura, Ippei (2011): Zōshoku suru shāman: Mongoru buriyato ni okeru shāmanizumu to esunisiti 増殖するシャーマン：モンゴル・ブリヤートにおけるシャーマニズムとエスニ シティ(The Proliferation of Shamans: shamanism and ethnicity among the MongolBuryats). Yokohama: Shumpūsha 春風社.

Shimamura, Ippei (2014): The Roots Seekers: Shamanism and Ethnicity among the Mongol Buryats. Yokohama: Shumpusha Publishing.

Shimamura, Ippei (2017): “A Pandemic of Shamans: the Overturning of Social Relationships, the Fracturing of Community, and the Diverging of Morality in Contemporary Mongolian Shamanism". SHAMAN Uournal of International Society for Academic Research on Shamanism) 26.2: 93-136.

Shimamura, Ippei (2018): “Keshin rama no kokyō wo tazunete - Mongoru chūseibu no tabi kara”化身ラマたちの故郷を訪放てーモンゴル国中西部の旅から (In search of the homeland of reincarnated lamas: from the field trip around Midwestern Mongolia). Kikan Minzokugaku 季刊民族学 (Quarterly Ethnology). 42.2: 5-20.

Shirendev, B. et.al. (1969): Bügd Nairamdakh Mongol Ard Ulsyn Tüükh: Gutdgaar bot' (The History of Mongolian People's Republic: volume 3). Ulaanbaatar: Ulsyn Khevleliin Khereg Erkhlekh Khoroo.

Shnirelman, Victor (2017): “How to Become the 'Slavic-Aryans': The Founders of the Russian Neo-Paganism and Their Ambitions". In: Religion and Magic in Socialist and Post-Socialist Contexts 1: Historic and Ethnographic Case Studies of Orthodoxy, Heterodoxy, and Alternative Spirituality. Edited by Alexsandra Cotofanaand James M. Nice. Ibidem-Verlag: Stuttgart, 75-98.

Soninbayar, Sh. (1995): Gandantegchinlen khiid, shashiny deed suruuliin khraangui tüükh tsagaan lavain duun egshig khemeekh orshivoi (The Melody of White Conch: A Brief History of Gandantegchenling Monastery and the Buddhist Institute). Ulaanbaatar: Yesön-erdene.

Takizawa, Katsuhiko (2016): Ekkyō suru shūkyō - Mongoru no fukuinha: Posto shakaishugi mongoru ni okeru shūkyō fukkō to fukuinha kirisutokyō no taitō 越境する宗教: モンゴルの 福音派: ポスト社会主義モンゴルにおける宗教復興と福音派キリス卜教の台頭 (The border-crossing religion, or Mongolian Evangelicals-Religious revival in post Socialist Mongolia and the rise of evangelicalism). Tokyo: Shinsensha.

Vanchu, Anthony J. (1997): “Technology as Esoteric Cosmology in Early Soviet Literature”.In: The Occult in Russian and Soviet Culture. Edited by Bernice Glatzer Rosenthal. Ithaca and London: Cornell University Press, 203-222.

Wallace, Vesna A. (2015a): "Envisioning a Mongolian Buddhist Identity through Chinggis Khan”. In: Buddhism in Mongolian History, Culture, and Society. Edited by Vesna A. Wallace. Oxford: Oxford University Press, 70-92. 
Wallace, Vesna A. (2015b): “How Vajrapāni became a Mongol”. In: Buddhism in Mongolian History, Culture, and Society. Edited by Vesna A. Wallace. Oxford: Oxford University Press, 179-201.

Weber, Max (1993 [1920]): The Sociology of Religion Translated by Ephraim Fischoff. Boston: Beacon Press.

Wikipedia (2019): “Bhutanese painted thanka of Milarepa (1052-1135)”, Late 19th-early twentieth Century, Dhodeydrag Gonpa, Thimphu, Bhutan. https://commons.wikimedia.org/ wiki/File:Bhutanese_painted_thanka_of_Milarepa_(1052-1135),_Late_19th-early_20th_ Century,_Dhodeydrag_Gonpa,_Thimphu,_Bhutan.jpg (08/27/2019).

Wittgenstein, Ludwig (1965): The Blue and Brown Books. New York: Harper Perennial.

Yamada, Takako (2004): "Symbiosis with nature: A Messenger for the reconstructing of Sakha Ethnicity and identity”. In: Senri Ethnological Studies 66. Circumpolar Ethnicity and Identity. Edited by Takashi Irimoto and Takako Yamada. Osaka: National Museum of Ethnology, 217-230. 